BUREAU OF ENTOHOLOGY AND PLANT QUARANTINE ARTICLES

PUBLISHED IN 1947

Compiled by
Division of Insect Pest Survey and Information

United States Department of Agriculture Agricultural Research Administrution Bureau of Entomology and Plant Guarantine 


\section{BUREAU OF ENTOMOLOGY AND PLANT QUARANTINE ARTICLES \\ PUBLISHED IN 1947}

Complled by the Division of

Insect Pest Survey and Information

This list consists of articles by Bureau workers published within the Department or in outside periodicals during 1947. The articles are grouped according to the subject matter. The numes of authors not members of this Bureau are indicated by asterisks (*). The numbers in parentheses are inserted for convenience in using the index and are not part of the reference.

Copies of processed publications of the Bureau-E and ET serles and special supplements, to the Insect Pest Survey--and printed publications of the Department may be obtained by writing to the Bureau of Entomology and Plant Quarantine, Washington 25, D. C. Reprints of articles published in outsiae periodicals are not generally available for distribution.

\section{TABLE OF CONTENTS}

Bees and pollination.......... 2
Cereul, forage, and sugarcane insects....................

Cotton insects............. 5

Equipment and methods........ 6

Forest and shade-tree insects and termites.............. 8

Fruit insects, including the Iapanese beeile........... 10

Insecticios--chemical papers.................... 13

Insecticides--general papers.. 16
Insects affecting man and animals.................. 17

Plant-dlsegas control......... 21

Plant quarantines............ 22

Stored-products pests........ 22

Taxonomy................... 23

Truck crop, garden, and greenhouse insect.s.........27 Bibliographies, literature revleris, aná lists.......... 30 Miscellaneous............... 31 Author index............... 33 
(1) Bohart, G. E.

Fild Bees in Relation to Alfalfa Pollination. Fara and Home Sc1. JUtah Agr. Expt. Sta.] 8 (4): 13-14. December.

(2) Farrar, C. L.

More Boney From Bees. U. S. Dept. Agr. Yearbook (Science in Farming) 1943-1947: 680-685.

(3)

Loseme Losses Anong Package Bees as Related to Queen Supersedure and Eoner I1elds. Jour. Econ. Bnt. 40 (3): 334-338. June.

(4) Hall, David G.

Bees Tailor-lade for Your Crops. Farm Jour. I (12): 24-25. December.

(5) Hambleton, J.I.

Does Beekeeplng Have a Part in Reclamation Planning?

Reclamation Era [U. S. Dept. Int.] 33 (8): 181, 182. August.

(6)

The Establishment of Two New Legume Seed Research Centers. oleanings Bee Cult. 75 (5): 27. Hay.

(7) Holst, E. C.

$\triangle$ Bonus From Foulbrood. U. S. Dept. Agr. Yearbook (Science in Farning) 1943-1947: 686-688.

(8) Mackensen, Otto

The Effect of Carbon Dioxide on Inttial Orlposition of Artiflclally Inseminated and Virgin Queen Boes. Jour. Econ. Bnt. 40 (3) \& 344-349. June.

(9) NoGregor, S. E., Caster, A. B.,* and Frost, Marvin H., Jr.* Honerber Los8e8 as Related to Crop Dusting With Arsenicals. Ar18. Agr. Expt. Sta. Tech. Bul. 114, pp. 221-246. October.

(10) - - and Vorhles, C. T.*

Beekeeplag liear Cotton M1elds Dusted F1th DDT. Ar1z. Agr. Bxpt. Sta. Bul. 207, 19 pp. June.

(11) Oertel, Bverett

Sugar Concentration of Some Loulslana Honey Plants. La. Agr. Expt. Sta. Inn. Rpt. 1945-1946: 116-117. June.

(12) Sturtevant, A. P.

News $\triangle$ bout Bee D1seases. 0. S. Dept. Agr. Iearbook (Sclence

in Farming) 1943-19478 674-679. 
BEES AND POLLINATION--Continued

(13) Vensell, Geo. H., and Todd, Frank I.

Honeybees and Other Bees Pollinate the Alfalfa Seed Crop in

Jtah. Gleanings Bee Cult. 75 (3): 136-139, 183. March.

\section{CEREAT, FORAGE, AND SUGARCANE INSECTS}

(14) Arbuthnot, B. D., Jones, D. F., Certer, S. M., and Lloyd, G. ..* The Colonlzation of Parasites of the Buropean Corn Borer in the Unlted States in 1946. U. S. Sur. Bnt. and Plant Quar. Insect Pest Survey Spec. Sup. (1947) 6, 3 pp. Apr1l.

(15) Jones, D. .., Carter, S. H., and Lloyd, G. N.* The Colonization of Parasites of the Buropean Corn Borer in the Unfted States in 1947. U. S. Bur. Int. and Plant Quar. Insect Pest Survey Spec. Sup. (1947) 9, 5 pp. November.

(16) Baker, H. A.

Control of Forsge Pests. U. S. Dept. Agr. Itearbook (Sclence in Farming) 1943-1947: 651-654.

(17)

The Horm Hith a 37 Milion Dollar Appetite. 48r. Comment [5. I. DuPont de Eenours and Co. $2(2): 3-5$. June.

(18) and Bradley, T. G.

Insecticldal Treatments for the Control of the European Corn Borer. J. S. Bur. Int. and Plant Quar. I-718, 4 pp. April. Rev13ed, May 1947. [Processed.]

(29) Berry, Paul A.

Inveatigations on the Hite-fringed Beetle Groun (Graphopnathus app.) ir South America. Jour. Econ. Ent. 40 (5): 705-709. netohsic

(20) Cartwight, N. Q.

Hessian Fy Survey at Harvesttine, 1947. U. S. Bur. Int. and Plant Quar. Insect Pest Survey Spec. Sup. (1947) 8, 3 pp., 11lus. Septeabor.

(21) and Noble, T. B.

Studies on Blological Races of the Hessian Fly. Jour. Agr. Res. 75 (4): 147-153. August.

(22) Douglas, T. 1.

The Effect of Husk Extension and Tightness on Earrorm Damage to Corn. Jour. Econ. Ent. 40 (5):661-66́4. October.

(23) Gaddls, B. M., and Roberts, R. A.

Finite-fringed Beetle Outlook. Central Plant Board Conf.

23: 42-49. March. 
CEREAL, FORAGE, AND SUGARCANE INSECTS--Continued

(24) Grayson, J. M., * and Poos, F. W.

The Southern Corn Rootworm as a Pest of Peanuts. Jour. Econ. Ent. 40 (2): 251-256. April.

(25) Hinman, E. J., and Cowan, F. T.

New Insecticides in Grasshopper Control. D. S. Bur. Ent. and Plant Quar. 1-722, 21 pp. Hay. [Processed.]

(26) Ingram, J. H., Bynum, E. K., and Charpent1er, I. J.

Iffect of $2,4-D$ on Sugarcane Borer. (Scientific Note) Jour. Econ. Int. 40 (5): 745-746. October.

(27) Bynum, E. K., Baley, K. E., and Charpent1er, L. J.

Tests Fith Hew Insecticides for Control of the Sugarcane Borer. Jour. Econ. Ent. 40 (6): 779-781. December.

(28) Bynum, E. K., and Mathes, Ralph

Research on Sugarcane-Insect Control Conducted by the Houma, La., Laboratory of the Bureau of Entomology and Plant Quarantine. Sugar Jour. 9 (11): 23-24. April.

(29) Bynum, E. X., Smith, C. I., and Dugas, A. I. Recommendations for the Control of the Sugarcane Borer in Loulsiana in 1947 by Dusting With Cryol1te. Sugar Bul. 25 (12): 89-90. March.

(30) Jones, D. R., Carter, S. H., and Cosenza, A. V.

The Fleld Status of Paras1te日 of the European Corn Borer at the Close of the 1945 Season. 0. S. Bur. Ent. ond Plant Quar. Insect Pest Survey Spec. Sup. (1947 3, 6 pp. March.

(31) Packard, C. M., Bayles, B. B.,* and Aamodt, O. S.*

Crops That Res1st Insects. U. S. Dept. Agr. Iearbook

(Science in Farming) 1943-1947: 648-650.

(32) Parker, J.R.

Comments and Suggestions on Locust Control in Argentina. U. S. Bur. Ent. and Plant Guar. E-734, 14 pp. September. [Processed.]

(33) Patch, L. H.

Manual Infestetion of Dent Corn to Study Resistance to European Corn Borer. Jour. Econ. Ent. 40 (5): 667-671. October.

(34) Questel, D. D., and Connin, R. V.

A Chemical Treatment of Soll Which Produces Plent T1ssue Lethal to European Corn Borer. Jour. Econ. Int. 40 (6): 914-915. December.

(35) Rockwood, L. P., Z1mmermsn, S. K., end Chamberlin, R. T. The Wheat Stem Maggots of the Genus Meromyza in the Pacif'1c Northwest. U. S. Dept. Agr. Tech. Bul. 928,18 pp., 111 s. 
CEREAL, FORAGE, AND SUGARCANE INSECTS--ContInUOd

(36) พ1lson, C. C.

Control of the Devastating Grasshopper in Califormia. Cal1f. Dept. Agr. Bul. 37 (3): 97-102. July-8eptember.

\section{COTTOM INSECTS}

(37) Bondy, F. F.

Results Obtained From Use of Varfous Insecticides in Cotton Insect Control: Pee Dee Experinent Stat1on, Florence, S. C. Southeastern Cotton Ingect Control Conf. Rpt. 19478 10-17. December. [Processed.]

(38) Chapman, A. J., RIchmond, C. A.,* and Flfe, L. C.

Comparative Toxicity of Benzene Hexachloride and DDT to Thrips on Cotton and Onions. (Scientific Note) Jour. Econ. Ent. $40(4): 575-576$. August.

(39) Conn, F. E., and Alderdice, J. A.

A New Procedure for Pink Bollworm Control. Acco Press 25 (6) : 8-12. June.

(40) Curl, L. F.

The Pink Bollwore Situation Lay 1, 1947. Acco Press 25 (6): 4-8. June.

(41) Eving, K. P.

Experimental Use of Promising New Insecticides on Cotton. 1cco Press 25 (6): 1-2. June.

(42) Parencie, C. R., Jr., and Ivy, E. E.

Cotton-Insect Control Pith Benzene Hexachloride, Alone or in Mxture W1th DDT. Jour. Econ. Ent. 40 (3): 374-381. June.

(43) Fife, L. C., Shiller, Ivan, and Chapman, A. J.

Pink Bollworm Carry-Over From One Cotton Crop to the Hext in the Lower Rio Grande Valley. Jour. Econ. Ent. $40(4)=$ 540-545. August.

(44) Gaines, R. C., Young, Y. T., and Smith, G. I.

Calcium Arsenate and N1cotine to Control Boll Weev1l and Cotton Aph1a. (Scientific Note) Jour. Econ. Ent. 40 (4): 600-603. August.

(45) GuIl, P. N.,* and Dunnam, E.

Experiments in Chemical Cotton Defoliation. Agr. Chem. $2(6)$ : 33, 35. June.

(46) Harned, R. R.

Insecticides for Cotton. U. S. Dept. Agr. Yearbook (Science in Farming) 1943-1947: 655-658. 
(47) Barned, R. W.

The Prospects for Cotton-Insect Control in 1948. Southeastern Cotton Insect Control Conf. Rpt. 1947: 28-31. December. [Processed.7

(48) IFy, E. E., and Ewing, K. P.

Laboratory and Cage Tests With Newer Insecticides to Control Cotton Insects. (Scientific Note) Jour. Econ. Ent. 40 (4): 568-569. August.

(49) Parencia, C. F., Jr., and Ewing, K. P.

A Chlorinated Camphene for Control of Cotton Insects. Jour. Econ. Ent. 40 (4): 513-517. August.

(50) Rainwater, C. F.

Some Insecticides Causing Boll Weevil Mortality Inside of Punctured Cotton Squares. (Scientific Note) Jour. Econ. Ent. 40 (6): 923-925. December.

(51) and Bondy, Floyd F.

New Insecticides to Control Boll Weevil and Cotton Aphid. Jour. Econ. Ent. 40 (3): 371-373. June.

\section{EQUIPMENT AND METHODS}

(52) Barnes, E. C., Caley, H. T., Fales, John H., Henderson, L. S., and Rinell1, H. R.

Aerosol Technique Provides Plant-Scale Insect Control.

Chem. Indus. 60 (2): 238-240, 339. February.

(53) Cartwright, N. B., and Luginb1ll, Philip

4 Notorized Aspirator. U. S. Bur. Ent. and Plant Quar. ET-244, 2 pp., 11lus. September. [Processed.]

(54) Chisholn, R. D., Koblitsky, L., Pest, W. C., and Burgess, E. D. Insecticide Duster. U. S. Bur. Ent. and Plant quar. EI-237, 3 pp., 1llus. April. [Processed.]

(55) Cook, Willian C., and Lane, Merton C.

The Application of Soll Fumigants With a Plow. U. S. Bur. Ent. and Plant Quar. ET-236, 3 pp., 1llus. March. Processed

(56) Fulton, R. A., and Berlin, F. D.

$\triangle$ Glass Container for 08 in Studying Aerosol Solutions. J. S. Bur. Ent. and Plant Guar. ET-246, 2 pp., 11lus. october. [Processed]

Berlin, F. D., and Bochert, R. S., Jr.

A Laboratory Method for Pllling Aerosol Containers. U. S. Bur. Ent. and Plant Quar. ET-245, 4 pp., 1llus. October. [Processed] 
(58) Getzendaner, C. T., and Dat18, E. T.

A Trap Unit for Insect Emergence Cages. U. S. Bur. Bat. and Plant Quar. ET-242, 3 pp., 11lus. September. [Processed.]

(59) Husman, C. H., Longcoy, O. H., and Hensley, B. S.

Equipment for the DIspersal of DDI Insecticldes by Means of Alrcraft. 0 . S. Bur. Ent. and Plant quar. ET-228, 17 pp., 111uis. May. [Processed.]

(60) Latta, Randall, and Goodhue, L. D. Aerosols for Insects. J. S. Dept. Agr. Tearbook (Science in Farming) $1943-478623-627$.

(62) Mann, H. D.

A Dual-Purpose Extraction Rack. U. S. Bur. Ent. and plant Quar. ET-243, 4 pp., 11lus. September. [Processed.]

(62) MoGorran, E. R., and Fales, J. H.

Collecting and Felghing Tube for Insectlcidal Aerosols. U. S. Bur. Ent. and Plant Quar. ET-24l, 5 pp., 1llus. September. [Processed.]

(63) and Fales, J. H.

Insecticldal Aerosol Progress. Soap and Sanft. Chem. 23 (2): 124-125, 169. February.

(64) and Fales, J. H.

Swinging-Shutter Apparatus for Measuring Smell Dosages of Insecticläal Aerosol. U. S. Bur. Fnt. and Plant Guar. ET-239, 7 pp., 11lus. June. [Processed.]

(65) Potts, S. F.

Hew Method to Apply Concentrated Spray. South. Planter 108 (z): 22. February.

(66) Potts, S. F., and Spencer, R. A.*

A Small Portable Mist Blower for Applying Concentrated Spray.

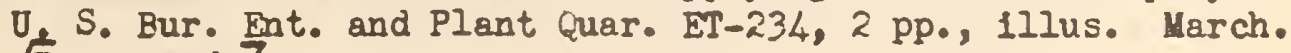
[Processed.]

(67) Rusk, Harold $\%$.

Inexpensive Replacement Elements for Laboratory Hot Plates. O. S. Bur. Ent. and Plant Quar. ET-235, 3 pp., 1llus. March. [Processed.]

(68) Siegler, E. H.

Leaf-Disk Technique for Laboratory Use of Acaricides. Jour. Econ. Ent. $40(2): 280$. April.

(69) Simmons, Perez.

Lamps for Use Fith the Binocular Microscope. U. S. Bur. Ent. and Plant Quar. ET-248, 2 pp., 1llus. November. [Processed.] 
(70) Yeomans, A. H., and Bodenstein, F. G. An Exhaust Aerosol Generator for 1-1/2 Horsepower Motors.

U. S. Bur. Ent. and Plant Quar. ET-238, 6 pp., 11lus. Yay. [Processed.]

FOREST AND SHADE-TREE INSECTS AND TERUITES

(TI) Inderson, Roger F.

Saratoga Spittlebug Injury to P1ne. Jour. Econ. Ent. 40 (1): 26-33. February.

(72)

The Saratoga Spittlebug. Jour. Econ. Ent. 40 (5): 695-701. October.

(73) Berry, Paul A.

Oriposition Habits and Rarly Stages of a Eucharld (Kapala sp.) Ent. Soc. Mash. Proc. 49: 77-80. March.

(74) Bess, Henry A., Spurr, Stephen H., * and Littlefield, E. W.* Forest Site Conditions and the Gypsy Moth. Harvard Forest Bul. 22, 56 pp.

(75) Bonberg, J. T.

An Experimental Cutting for Pine Beetle Control by the MeCloud River Lumber Company. Timberman 48 (7): 128-130. May.

(76) Brewer, E. G.

Report on Dutch Elm Disease. Amer. Forests $53(3): 124,141$. March.

(77) Corl1ss, J. U.

Gypsy Moth Control With DDT. Trees [Jour. Amer. Arboriculture] 8 (1): 7, 16. November-December.

(78) Dowden, Philip B.

Experiments W1th DDT for the Control of the Gypsy Moth, Particularly With Aerlal Equipment. O. S. Bur. Ent. and Plant Quar. E-726, 13 pp. June. [Processed.]

(79) Eaton, C. B., Jaynes, H. A., Beal, J. A., and Muiry, J. H.* Airplane Spraylng Fith DDT for Spruce Budworm Control. Forest Insect Invest1gations [Ottawa, Canadg] B1mo. Prog. Rpt. $3(5): 3-4$. Septenber-October.

(80) Evenden, James C.

Progress in Forest Insect Control, W1 th Speclal Reference to the Tussock Moth Campaign. West. Forestry and Conserv. Assoc. Proc. 1947. December.

(81) Fenner, L. M., and Fate, L. B. Ceratostome 1la ulmi on Elm Bark Treated with 2,4-D1chlorophenoxyzcet1c Ac1d. Phytopathology 37 (12): 925-928. December. 
FOREST AND SHACE-TREE IMSECTS AND TERUITES-COntinued

(82) Hal1, Dav1d G.

Tussock Hoth Hits Idaho. TImborman 48 (6) \& 46, 48. Apr1I.

(83) Hoffman, C. H., Bepting, G. H., * and Roth, E. R.*

A Twig Droop of Thite Pine Caused by Pineus (Chiraides). Jour. Icon. Int. 40 (2) $829-231$. August.

(84) Hunt, Geo. M., and Snyder, T. E.

An International Termite Exposure Test. Amer. Food Preservers' Assoc. 18th Prog. Rpt., 16 pp. April.

(85) Villiron, H. E.

A Mmarid Which Parasit1zog to Eggs of the Saratoga Spittlobug. Ent. Soc. Amer. Ann. $408217-220$. Jure.

(ع6)

A Hew Aphelinid Egg Parasito of the Saretoga Splttlebug, Aphrophora saratogensis (F1tch). Bnt. Soc. Fash. Proc. $49(7)$ : 193-197. Octobor.

(87) Potts, S. F.

Concentrated Spray Application. Natl. Shade Tree Conf. 23 ? $183-193$.

(88) Romney, V. E., Thitten, R. R., snd Madden, A. H. DDT Fettable Powders and Emulsions Used on American and Asiatic Elms. Jour. Econ. Eat. 40 (3) 830 . June.

(89) Sherls, R. A.

Arplane Spraylng for Gypsy Noth Control. Jour. Forestry 45: 712-714. October.

(90) Snyder, T. E.

Cooperation With the Pest Control Industry. Pests 15 (9): 12. September.

(91)

Do Iou Forry About Termites? Better Homes and Gardens 25 (10): 144-147. June.

(92)

Panama Test Homes Immune to Termite Attack After 21 Yearg. Food Preserv. Newr $25: 36-38,45$. May.

(93) Struble, G. R.

Twig Damage in Sugar Pine Caused by the Cone Beetle. (Notes) Jour. Forestry 45 (1): 48-50. January.

(94) Welss, Freeman, * and St. Georgo, R. A.

Culture, Diseases, and Pests of the Box Tree. D. S. Dept. Agr. Farners' Bul. 1855, rev., 18 pp. Apr11. 
FOREST AKD SHADE-TREE IHSECTS AND TERITES-ContInued

(95) Wester, Horace P.,* and St. Goorgo, R. A.

Life History and Control of the Nebrora, Homadaula albizzlae. Jour. Econ, Ent. 40 (4): 546-553. August.

(96) Iuill, J. S.

DDT and Alrplanes for Spraying Forests, South. Lumbernan 1748 46, 48, May.

\section{FRUIT INSECTS, INCLUDING JAPANESE BERTLE}

(97) Barnes, D. F.

Notos on DDT-Sulfur and Cryolite-Sulfur Duats for Control of Grape Leaf Folder. Calif. Cult. $94(9): 285.4$ pril. 1180 Pacif1c Bural Press, May 10, p. 422.

(98) and Lindgren, D. I.

Beotle Infestation In Dates. Deto Growers' Inst. Ann. Rpt. (1946) $23834-35$. January.

(99) and LIndgren, D. L.

Progress of Nork on Begtle Infestation in Dates. Date Growers' Inst. Ann. Rpt. (1947) 248 3-4. December.

(200) Berry, Paul A.

Anthonoms vestitus and Its Natural memies in Poru, and Their Importation into the United States. Jour. Econ. Int. 40 (6): 801-894. December.

(101) Clancy, D. W., and Pollard, H. N.

Further Experiments in the Parasitiation of Mealybugs. (Sc1entif1c Note8) Jour. Econ. Fat. 40 (4): 578-579. August.

(102) Flaring, N. E.

Chlordane Promising for Control of Japanese Beotle in Turf. Jour. Econ. Ent. 40 (6), 932-933. Decenber.

(203)

Effect on Plants of DDT Applied to Soll for the Destruction of Japanese Beetle Larvae. 0 . S. Bur, Ent. and Plant Quar. P-737, 20 pp. Decomber. [Processed,]

(104)

Summary of Experimente 11 th DDT to Control the Japanease Beetle. O.S. Bur. Int. and Plant Quar. I-724, 22 pp. May. [Processed]

(105) and Maines, Farren म.

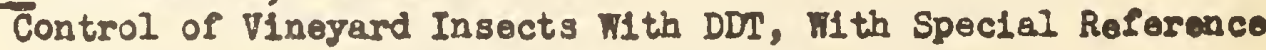
to the Japanese Beotle and the Grape Berry Moth. Jour. Econ. Ent. $40(6): 845-850$. December. 
FRUIT INSECTS, INCWODIHG JARANESE BEETLE-ContInued

(106) Fleming, H. E., and Maines, Warren $K_{0}$

The EffectIveness and Duration of Treatments Mith Technical DDT In Different Solls Against Larvue of the Japanese Beetle. U. S. Bur, Ent. and Plant Quar. E-716, 20 pp. March. [Processed]

(107) Gaddis, C. H., and Goodhus, L. D.

Treatment of Aeroplanes to Prevent Accidental Transportation of Japanese Beetles. Jour. Econ. Ent. 40 (2) : 240-244. Apr11.

(108) Badley, C. B.

Controlling the Japanese Beetle, J. S. Bur. Ent. and Plant Quar. [-727, 7 pp. June. [Processed.]

(109) Bamilton, D. \%.

Control of Pear Psylla and Codling Moth on Pears in the Hudson River Valley. N. I. State Hort. Soc. Proc. 92: 157-162.

(110)

New Insecticides for Control of Pear Psylla. Jour. Econ. Int. 40 (2): 234-236. Apri1.

(121) Johnson, 1. C., Bowen, C. H.,* and Phillips, G. L.

Report on Cooperative Experiments Conducted by the Bureau of Fntomology and Plant Cuarantine and the California State Departinent of Agriculture Relative to the Fumigation of Fruit and Nursery Stock Hosts of the Oriental Fruit Moth. U. S. Byr. Ent. and Plant Quar. E-7l, 42 pp., 11lus. January. [Processed.7

(112) Mathis, N.

Blology of the Florida Red Scale in Florida. Fla. Int. 29 $(2-3): 35$. Juls.

(113) Yoznette, G. F.

DDT for Control of the Pecan Feev11. Southeast. Pecan Growers' Assoc. Proc. 1947: 49-53. February.

(114)

DDI for Pecan Feev1l Control in the Southeastern States. U. S. Bur. Ent. and Plant Quar. E-723, 6 pp., 1llus. May. [Processed, 7

(125) Newcomer, E. J.

Evaluation of Materials for Controlling Orchard Mites and the Foolly Apple Aphid. Wash. State Hort. 1880c. Proc. 438 19-23. 
FRUIT INSECTS, INCLUDING JAPANESE BEETLE-Continued

(117) Nercomer, E. J.

Insecticides for Controlling the Pear Paylla. Wash. State Hort. Assoc. Proc. 438 45-46.

(118) Hiakels, C. B., and Plerce, W. C.

Effect of Flooding on Larvae of the Pecan Feev1l in the

Ground. Jour. Econ. Ent. $40(6)$; 921. December.

(119) Plummer, C. C., and Shar, J. G.

DDT and Benzene Hexachloride to Control Mexican Frult Fly. Jour. Econ. Ent. 40 (4) : 483-486. August.

(120) and Shaw, J. G.

Toxicants in 0118 for Control of the C1trus Blackfly. Jour. Econ. Ent. 40 (4): 499-504. August.

(121) Porter, B. A.

Another Year With DDT and Some Other New Orchard Chemicals. smer. Fruit Grower 67 (8): 15, 42, 43, 45. February.

(122)

Orchard Insect1cides. U. S. Dept. Agr. Yearbook (Sclence in Farming) 1943-1947: 659-662.

(123) Shaw, J. G.

Hosts and Distribution of Anastrepha serpentina in Northeastern Mexico. Jour. Econ. Bnt. 40 (1): 34-40. February.

(124)

Parasites of a Bag-Haking Plerid, Eucheira socialis, in Morelo8, Mexico. Jour. Econ. Ent. 40 (3) : 436-437. June.

(125) Simmons, Perez, Fisher, C. K., Condit, Ira J.,* Hansen, H. M.,* and Tyler, J. G.*

Caprification of Calimyrna FIgs. Summary of Three Iears' Research. Cal1f. Dept. Agr. Bul. 36 (3): 125-121. JulyAugust-September.

(126) Snapp, Ol1ver I.

Dichloroethyl Ether for Control of the Plum Curculio on Peach. Dow to Farth [Dow Chomical Co.] 3 (2): 16, 11lus. Fall issue.

(127)

Experiments in 1946 on the Control of Bugs That Cause Deformed Peaches. Jour. Econ. Ent. 40 (1): 135-136. February.

Recent Developments in the Control of the Plum Curculio and the Peachtree Borer. Tenn. State Hort. Soc. Proc. 41 27-33. Decenber. 
FRUIT INSECTS, INCLUDING JAPANESE BEETLE-ContInued

(129) Snapp, Oliver I., and Hollon, J. P.

Preliminary Experiments With Benzene Hexachloride for Plum Curculio Control on Peaches. Jour. Econ. Ent. 40 (3): 382-385. June.

(130) Stafford, E. H., * and Barnes, D. F. Control of Fig Scale. Cal1f. Cult. 94: 209. March.

(131) Steiner, L. F., Sumerland, S. A., McAllster, H. J., and Fahey, J. E. DDr for Control of the Codling Moth in the Middle West. Ind. Hort. Soc. Trans. (1946), p. 86. 1947.

(132) Van Leeuren, E. R.

Increasing Production of Codling Noth Eggs in an Oviposition Chamber. Jour. Econ. Ent. 40 (5): 744-745. October.

(133) White, Ralph $\mathrm{T}$.

Milky D1sease Infecting Cyclocephala Larvae in the Field. Jour. Econ. Bnt. 40 (6):912-914. December.

(134) Ietter, $\pi$. P., Jr.

Hew Insecticldes for Control of the Oriental Fruit Moth. Jour. Econ. Ent. 40 (2): 274-275. Apr11.

(135) Iothers, H. A.

DDT and the Foolly Apple Aphld Parasite Aphelinus mal1. Jour. Econ. $40(6)$ : 934. December.

(136) and Carlson, F. F.

A Spray for Destroying Overwintering Larvae of the Codling Moth on Apple Tree Trunks. U. S. Bur. Int. and Plant Quar. E-712, 7 pp. January. [Processed.]

(137) Iust, Harold R., Nelson, Howard D., Bustay, R. L., and Fulton, Robert, A.

Influence of Various Exposure-Concentretion Combinations on Mortality of the Callfornia Red Scale in HCN Fumigation. Jour. Econ. Ent. $40(6): 869-874$. Derember.

\section{IHSECTICIDES--CHEIICAL PAPERS}

(138) Bowen, C. V.

Report on Hicotine and Hornicotine Analysis. Assoc. Off. Agr. Cher. Jour. 30 (2): 315-319. May.

(139) Carter, R. H.

Estimation of DDI in Milk by Determination of Organic Chlorine. Analyt. Chem. 19 (1): 54. January.

(140)

Report on Methods for the Determination of DDT in Insecticlde Residues and in Animal Products. Assoc. Off. Agr. Chem. Jour. 30 (3): 456-463. August. 


\section{INSECIICIDES-CHEICAL PAPERS-Continued}

(14I) Cbisholn, R. D., and Koblitaly, I.

sffect of Light on DDT Residues. Agr. Chom, 2 (9) = 35, 37. Septamber.

(142) Cristol, S. J.

The Kinetice of the Alkaline Dehydrochlorination of the Benzene Hexachloride Isowers. The Mechanisa of SecondOrder Elinination Resctions. Aner. Chen. Soc. Jour. 69 (2) : 338-342. February.

(143) Soloway, S. B., and Heller, B. I.

Isolation of the 0,0'-DDr I somer from Technical DDT. Amer. Chem. Soc. Jour. 69 (3): 510-515. March.

(144) Cupples, H. I.

Interfacial Tension by the Ring Method: the Benzene-Fater Interface. Jour. Phys. and Collo1d Chesn. 51 (6): 13411345. November.

(145) Fahey, Jack E., and Rusk, Harold W. Ratio of Lablie Chlorine to Total Chlorine in DDT SprayReslcue Deposits in Soutbern Indiana Apple Orchards. Assoc. Off. Agr. Chom. Jour. 30 (2): 349-354. May.

(146) Fleck, E. E.

Anhydrous Ferrlc Chloride as a Rearrengenent Catalyst for Sore Chlorinated Diphenylethanes. Jour. Organic Chem. 12 (5): 708-712. September.

Report on Lethods for Analysis of DDT and Insecticldal Proparations Containing DDT. Assoc. Off. Agr. Cham. Jour. 30 (2): 329-324. May.

(148) Rulton, R. A., and Van Dyke, MIIdred J.

Determination of Sull Quantitles of HJdrogen Cyanido in

Insects and Plant IIssue. Indus, and Engin. Chem., Analyt. Ed. 19 (11): 922-923. November.

(149) Gertler, S. I., and Schechter, M. S.

A System for Storing Organic Chomicals. U. S. Bur. Fot. and Plant Quar. EI $-240,3$ pp. August. [Processed.]

(150) Gooden, E. L.

Evaluation of Pyrophyllite as an Insecticide Diluent. Jour. Econ. Ent. 40 (2): 270-273. April.

(151) Goodhue, L. D.

Determination of Freon-Insolubles in Pyrethrum Extract. Soap and Santt. Chem. 23 (1): 133, 135. January. and Hazen, A. C.

Viscosity and Density of Four Liquefied-Gas Aerosol Solutions Containing DDr. Analyt. Chem, 19 (4): 248-249. Apr11. 


\section{INSECTICIDES-CHEUICAL PAPERS-Continued}

(153) Baller, H. L., and Bozen, C. V.

Basic Facts About Benzene Hexachloride. Agr. Chem. 2 (1): 15-17. January.

(154) and Busbey, Ruth L.

The Chemistry of DDT. J. S. Dept. Agr. Tearbook (Science in Parming) 1943-1947: 616-622.

(155) Jacobson, M., snd Acres, Fred, Jr. Correction of the Source of "Affinin" (1-Isobuty1-2,6,8Decatrienoamide). Jour. Organic Chem. 12 (5): 731-732. Septeraber.

(156) and Haller, H. I.

The Insecticldal Component of Dugenla haitiensis Identifled as 1,8-Cineol. Aner. Chem. Soc. Jour. 69 (3): 709-710. March.

(157) LaForge, F. B., and Bartbel, $\pi$. F.

Constituents of Pyrethrum Flowera. XX. The Partial Synthesis of Pyrethrins and Cinerins and Their Relative Toxlcities. Jour. Organic Chen. 12 (1): 199-202. January.

(158) and Soloway, S. B.

Constituents of Pyrethrum Flovers. XXI. Revision of the Structure of Dihydrocinerolone. Amer. Chem. Soc. Jour. 69 (12): 2932-2935. December.

(159) and Soloway, S. B.

The Structure of Dihydrocinerolone. Amer. Chem. Soc. Jour. 69 (1): 186. January.

(160) Roark, R. C.

Some Promising Insecticldal Plants. Econ. Botang 1 (4): 437445. October-December.

(161) Schechter, M. S., Pogorelskin, M. A, and Haller, H. L. Colorinetric Determination of DDT in Milk and Fatty Materlals. sealyt. Chem. 19 (1): 51-53. January.

(162) Siegler, E. H., and Hall, Stanley, A.

Hexsethyl Tetraphosphate as an Insecticide. Jour. Econ. Ent. 40 (5): 722-724. October.

(163) Soloway, S. B., and LaForge, F. B.

A Claisen Condensation of a Primary Grignard Reagent. Amer. Cherr. Soc. Jour. $69(9): 2244-2245$. September.

(164) and Laporge, F. B.

The Synthesis of Dihydrocinerolone. Jour. Amer. Chem. Soc. 69 (4): 979-980. April. 
(165) Soloway, S. B., and LaForge, F. B.

The Synthesis of Some Beta-Leto Esters. Jour. Amer. Chem. Soc. 69 (11): 2677-2678. November.

(266) Wolsser, J.,* and Gooden, B. L.

Particle S1ze Reduction of DDT in Grinding with Diluents. Agr. Chem, 2 (8): 28-29. August.

\section{IHSECTICIDES-AERERII PAPERS}

(267) Bishopp, F. C.

Hew Insecticldes-a Progress Report on Results Being Obtained in Preliminery Studies. Agr. Chem. 1 (6): 19-22, 39-40. October.

(168) Bottger, G. T., and Lev1n, Clemence

Preliminary Tests of Synthet1c Organic Compounds as Insect1cldes. Part III. U. S. Bar. Ent. and Plant Quar. E-729, 23 pp., June; Part IV, E-738, 14 pp. December. [Processed.]

(169) Brannon, L. I.

Plperonyl Cyclonene and Piperonyl Butoxdde as Synergists with Rotenone. (Sclentific Note) Jour. Econ. Ent. 40 (6): 933934. December.

(170) Fales, J: H., MoGotran, E. R., and Fulton, R. A.

Gamma-Benzene Hexachlorlde in the Liquefied-Gas Aerosol, Jour. Econ. Ent. 40 (5): 754. October.

(171) Gertler, S. I.

A Revien of Laboratory Tests on the Toxicity of Some NSubstituted Benzamides to Various Insects. O. S. Bur. Ent. and Plant Quar. E-732, 12 pp. August. [Processed.]

(172) Hall, Davld G.

I Hew Rival for DDT-Hexaethyl Tetraphosphate. Flower Grower $34(4)$ : 339, 362. April.

(173)

(174) Baller, B. L.

Fartime Development of Insecticides. Indus, and Engin. Chowe $39(4): 467-473$. Apr11.

(175) Mayer, E. L., Talley, Horence B., and Woodward, C. F. Hicotine Insecticides. Part III--Dust Carrlers for Nicotine. U. S. Bur. Fnt. and Plant Quax. E-720, 11 pp. April. [Processed.] 
IHSECTICIDES-GERERAI PAPERS-COntInUEd

(176) Majer, Z. I., Me1l, L., * Saunders, D. H., and Noodward, C. F. H1cotine Insect1cides. Part IV-Preliminary Toxdcity Tests Nith Hicotinfure Salts. U. S. Bur. Ent. and Plant Quar. E-725, 10 pp. May. [Processod.]

(177) MoGorran, E. R., Bottger, G. T., Gersdorff, H. A., and Fales, J. H. Insecticidal Action of Heliopsis longipes and Erigeron spp. O. S. Bur. Fnt. and Plant Quar. E-736, 5 pp. November. [Processed.7

(278) Robwer, S. A.

What's thead for Insecticides. Soap and Senit. Chem. 23 (6): 135-137, 169. June.

(179) Rubin, Mas, B1rd, H. R. ,* Green, Nathan, and Carter, R. H. Toxdelty of DDT to Laylng Hens. Poultry Selence $26(4): 410$ 423. July.

(180) Slegler, E. H., and Bowen, C. V.

Tests for Synorgisa in Palred uxtures of Micotine, Hornicotine, and Anabssine. Jour. Econ. Ent. 40 (4): 576-577. August.

(181) Stage, H. H., and Irons, F.

Alr War Agalnst Pests. U. S. Dept. Agr. Yearbook (Science in Farming) 1943-1947: 835-838.

(182) Swingle, M. C., Gahan, J. B., and Phillips, A. M.

Derelopmental Tests of Syathetic Organic Compounds as Insect1cldes. Part I. U. S. Bur. Bnt. and Plant Quar. E-730, 57 pp. July. [Processed.]

\section{IUSECTS AFPECTIHG MAN AND ANIMALS}

(183) Bishopp, F. C.

Insect Control in Hospitals and Hones. Amer. Jour. Hursing $47(9)$ : 613-617. September.

(184) Blakeslee, E. B., and Bruce, W. G. DDI Sprays for the Control of the Gulf cosst rick--1 Preliminary Report. O. S. Bur. Bnt. and Plant Quar. E-719, 3 pp. Apr11. [Processed.] T1ssot, A. N., Bruce, W. G., and Sanders, D. A. DDI to Control the Gulf Coast Tick. Jour. Econ. Ent. 40 (5): 664-666. October.

(186) Bruce, $1 . G$. The Tall Louse, Hew Pest of Cattle in Florlda. Jour. Econ, int. $40(4): 590$. August. 
IMSECTS AFFECTIMG UN AND ANIUATS-Continued

(187) Burreli, R. H., Deonier, C. C., and Fisecup, C. B.

The Honspreading of Larvlc1da] 0118 on Florlda Faters. Mosquito Kers 7 (1): 11-13. March.

(188) Bushland, R. C.

Comparative Tests With DDI and Phenothiazine Against Two Alerlcan and Three New Gulnea Species of Mosqulto Larvae. Mosquito Ner8 7 (1): 14-17. Harch.

(189) Division of Insects Affecting Man and Animals.

Uses of Varfous DDT Formulations for the Control of Insects Affectins Animals. J. S. Bur. Int. and Plant Quar. E-724, 9 pp. March. [Processed.]

(190) Eddy, G. W.

Effect of thuldity on the Toxdclty of Certain Organic Compounds to Eggs of the Body Louse. Jour. Econ. Ent. 40 (1) 116-118. February.

(191) Gahan, James B., and Payno, George C.

Control of Anopheles Pseudopunctipennis in Mexico with DDI Residual Sprays Applied in Bulldings. Amer. Jour. Hyg. 45 (2): 123-132. March.

(192) Gersdorf, N. A.

Toxdclty to House Flies of the Pyrethrins and Cinerins, and Derivatives, in Relation to Chemical Structure. Jour. Econ. Ent. $40(6)$ : 878-882. December.

(193) GJullin, C. M.

Effect of Clothing Color on the Rate of Attack of Aedes Mosqu1toes. Jour. Econ. Bnt. 40 (3): 326-327. June.

(194) Gouck, H. K., and Smith, C. N. DDI for the Control of Food Ticks. Jour. Ecan. Ent. 40 (3) 8 303-308. June.

(195) Henderson, L. S.

DDT in the Home. J. S. Dept. Agr. Yearbook (Science in Farming) 1943-1947:643-647.

(1\%)

The Use of DDT and Other Methods of Insect Control in Dairy Plants. Milk Plant Monthly 36 (3): 54-56, 60. March.

(197) Incho, H. H., and Deonler, C. C. Comparative Toxicity of DDI to Three Representative Species of Mosquito Larvae. Mosquito News 7 (2): 67-69. June.

(198) Knlpling, E. F.

Hewer Synthetic Insecticides. Soap and Sanit. Chem. 23 (7): 127, 129, 131. July. 
INSECIS AFECIIMG YAN AND ARINALS-Continued

(199) Knipling, E. F.

Peste That Attack Men. U. S. Dept. Agr. Yearbook (Sclence in Farming) 1943-1947: 632-642.

(200)

Recent Developments in Insecticides of Interest to Pest Control Operators. Pests 15 (1): 10, 12, 14. February.

(201) Laake, E. F.

DDT Alds Livestock Production. Agr. Comment [E. I. DuPont de lemours and $\mathrm{Co}_{2} .72(3): 1,3$. August.

(202) and Bruce,

Controlling Pests of Stock. J. S. Dept. Agr. Yearbook (Sclence in Faraing) 1943-1947: 670-673.

(203) Laller, V. K. ,* Hochberg, S.,* Hodges, K.,* Filson, I.,* Fales, J. H., and Latta, Randell.

The Influence of the Particle Size of Homogeneous Insecticidal serosols on the Mortellty of Mosquitoes in Confined Atmospheres. Jour. Collo1d Sc1.2 (6): 539-549. December.

(204) Latts, Randall, Anderson, L. D., Rogers, E. E., Laller, V. K. ,* Hochberg, S.,* Lauterbach, H., * and Johnson, I. ,*

The Effect of Particle Size and Velocity of Movement of DDT Aerosols in a find Tunnel on the Mortality of Mosquitoes. Fash. Acad. Sc1. Jour. 37 (II): 397-407. November.

(205) Indquist, A. W., Madden, A. B., and Milson, H. G.

Pro-Treating House Flies Fith Synerg1sts Before Applying Pyrethrum Sprays. (Scientific Note) Jour. Econ. Ent. 40 (3) : 426-427. June.

(206) and Roth, A. R.

Specles and Incldence of Cattle Grubs in Oregon. Jour. Econ. Ent. $40(6): 930$. December.

(207) Induska, J, P., and Morton, F. A.

Benzene Hexachloride for Area Control of Trombiculid Mites. Amer. Jour. Trop. Med. 27 (6): 77-777. June.

(208) and Morton, F. A.

Determining the Repellency of Solld Chemicals to Mosquitoes. Jour. Econ. Bnt. $40(4): 562-563$. August.

(209) Madden, A. H., Lindquist, A. W., and Jones, H. A.

Fly Larvicide Tests. Soep and San1t. Chem. 23 (3): 141. March.

(210) Lindçuist, A. W., and Longcoy, O. M.

Control of Adult Sand Flies by Airplane Spraying Fith DDT. Fla. Ent. 29 (1): 5-10. January. 
INSECTS AFFECTING MAN AND ANIMALS-Continued

(2II) Medden, A. H., Schroeder, H. O., and Lindquist, A. W.

Residual Spray Applications to Salt-larsh and Jungle Vegotation for Control of Mosquitoes. Jour. Econ. Ent. 40 (1): 129-123. February.

(212) Oran, P. H., and Christenson, L. D.

Malaria and Other Insect-Borne Diseases in the South Pacific Campaign, 1942-1945. Part III. Amer. Jour. Trop. Med. 27 (3): 91-117. May.

(213) Orlando, Fla., Laboratory, O. S. Bureau of Entomology and Plant Qusrantine.

Results of Screening Tests With Materials Evaluated as Insecticides, Miticides, and Repellents, at the Orlando, Fla., Laboratory, April 1942 to April 1947. U. S. Bur. Ent. and Plant Quar. E-733, 235 pp. September. [Processer.]

(214) P1quett, P. G., Nelson, R. H., and MoGovran, E. R.

Synergism in Pyrethrum-Piperonyl Cyclohexenone Rosch Powders. (Scientific Note) Jour. Econ. Ent. 40 (4) : 577-578. August.

(215) Roth, A. R., Yates, W. F., and Lindquist, A. F.

Preliminary Studies of Larvicides on Snow-irater Mosquitoes. Mosqui to News 7 (4): 154-156. December.

(216) Bade, C. S.

DDT for the Control of the Gulf Cosst Tick. Jour. Econ. Ent. 40 (3): 301-303. June.

(217)

(218)

Goat Lice and Their Control. Better Goatkeeping 2 (12): 476. July. and Graham, O. H.

A New Treatment for Screwrorms in Livestock. U. S. Bur. Ent. and Plant Quer. E-708 (Revision), 3 pp. January. [Processed.7

(219) Snith, Carroll N., and Gouck, Harry K.

The Control of Chiggers in Foodland Plots. Jour. Econ. Ent. 40 (6): 790-794. December.

(220) Snyder, F. M., and Morton, F. A.

Benzyl Benzoate-Dibutyl Phthalate Mixture for Impregnation of Clothing. Jour. Econ. Ent. 40 (4): 58̣6. August.

(221) Stage, H. H.

Control de Nosquitoes Mediante Nuevos Metodos e Insect1cidas y Aparatos de Reciente Manufactura. Tijeretazos Sobre Malarla $11(1-2)$ : 32-41. March-June. 
INSECTS AFFECTING MAN AND ANIMALS-Cont1nued

(222) Stage, H. H.

DDF to Control Insects Affacting Man and Animals in a Tropical V1llage. Jour. Econ. Ent. 40 (6): 759-761. December.

(223) and Giglioli, George*

Observations on Mosquitoes and Malaria Control in the Caribbean Arsa. Part II-British Guiana. Mosquito News 7 (2): 73-76. June.

(224) and Gillotte, H. P. S.* Observations on Mosquitoes and Malaria Control in the Car1bbean Area. Part III-Trinidad. Mosquito News 7 (4): 157-159. Decerabor.

(225) _ and Knlpling, E. F. Recently Developed Insecticldes for Controlling the Arthropod Vectors of Trphus. Primera Reunion Interamericana Del T1fo 1: 275-285.

(226) Travis, B. V.

Mosquito Repellents. Amer. Perfumer and Essential 011 Rer. 50: 141-142. August.

(227)

New Insact Repellents. J. S. Dept. Agr. Yearbook (Science in Farming) 1943-1947: 628-631.

(228) Iates, .. $_{0}$, and Gjullin, C. M.

Pre-hatching Applicetions of DDT Larvicides on Floodwater sedes Mosquitoes. Mosquito Ners 7 (1): 4-6. March.

\section{PLANT-DISEASE CONTROL}

(229) Hartman, H. J., and Offord, H. R.

The Eradication of Polson-Oak at Camp Adair, Oregon. Jour. Forestry 45 (2): 105-112. February.

(230) Limber, D. P.

The Observed Frequency of Mature Pycnidia of Septoria gladioll on Gladiolus Corms. Phytopathology 37 (3): 190191. March.

(231) Martin, J. F.

Sanitation in Barberry Erad1cet10n. Ader. Wurseryman 85

(8): 14. Apr11.

(232) Offord, H. R.

The Control of Feed Hosts of Plant Diserses. Minutes, Hestern Heed Control Conf. 9: 18-21. February. 


\section{PLAIT-DISEASE CONTROL-Cont1nued}

(233) Prout, C.,* and Ritter, L. B. White Pine in Minnesota. Conserv. Volunteer 10 (56): 37-41. january-February.

(234) PüZnam, H. N.

White Pine Blister Rust Spreads Southward in Indiana and Ohio. Forestry News $2(8): 16$. August.

(235) Quick, C.R.

Germination of Phacelia Seeds. Madrono 9 (1): 17-20. January.

(236) Riker, A. J., Kouba, T. F., and Henry, B. W.

The Influence of Temperature and Humldity on the Development of Thite Pine Blister Rust on Ribes Leaves. (Note) Phy topathology 37 (1): 19. January.

(237) S1sson, M. A.

Presert StatuB of the Peach Mosalc Control Program in Testern Colorado. West. Colo. Hort. Soc. Trans. L8 155-161. Januคry.

(238) Yost, H. E., and Hepting, G. H.*

The Development of Thite Pine Blister Rust in an Onprotected Area in North Carolina. Plant D1sease Rptr. 31 (1): 26. January. [Processed.]

\section{PLANT QUARANTINES}

(239) Becker, G. C.

Importing Cotton Waste Samples. Waste Trade Jour., Internatl. Ed. 1947.

(2.40) Cooley, C. E.

International AIr Commerce and Plant Guarantines. Jour. Econ. Ent. 40 (1): 129-132. February.

\section{STORED-PRODUCTS PESTS}

(24I) Cotton, R. T.

Pests In Stored Products. U. S. Dept. Agr. Yearbook (Science in Farming) 1943-1947: 874-878.

(242) and Frankenfeld, J. C.

Dusts for Use Against Stored Grain Insects. Down to Earth [Dow Chemical Co.] $3(1): 9-11$. Summer issue. and Walkden, H. H. Chem. 2 (1): 33-35. May. 


\section{TAXONOMY}

(244) Anderson, F. H.

A Terminology for the Anatomical Characters Useful in the Taxonomy of Weevil Larvae. Ent. Soc. Wash. Proc. 49 (5): 123-132. May.

(245)

Larvae of Some Genera of Anthribidae (Coleoptera). Ent. Soc. Amer. Ann. 408 489-517. September.

(2.46) Baker, E. H.

Noles on Mites of the Family Tydeidae (Acarina) With Descriptions of Two New Specles. Ent. Soc. Nash. Proc. 49 (5) : 133-136. May.

(247) Barber, H. S.

A New Schemat1za on Cordia in Trinidad (Coleoptera: Chrysomelidae). Mash. Acad. Sc1. Jolu. $37(7): 242-243$. Julg.

(248)

Diabrotica and Tro New Genera (Coleoptera: Chrysomelidae). Ent. Soc. Hash. Proc. 49 (6): 151-161. June.

(249)

On the Odd, or 1'18sue-paper, Beetle Supposed to be Thrlodrias contractus (Coleoptera: Demestidae). Ent. Soc. Amer. Ann. $40(2): 344-349$. June.

(250) Buchanan, L. I.

A Correction and Two New Races in Graphognathus (Whitefringed beetles) (Coleoptera:Curculionldae). Wash. Acad. Sc1. Jour. 37 (1): 19-22. January.

(2.51)

Hickory Curculios of the Genus Conotrachelus (Coleoptera: Curculionidae). Ent. Soc. Wash.Proc. $49(2): 41-54$. February.

$(25 \%)$

Notes on Cuban Curculionldae, With Descriptions of New Cenera and Species (Coleoptera). Soc. Cubana de Hist. Nat. "Fellpe Poey" Mem. 19 (1): 43-54. July.

(253) Clarke, J. F. Gates

A New Dichomer from Eastern United States (Lepidoptera: Gelechildae). Wash. Ent. Soc. Proc. 49 (7): 187-189. October.

$(254)$ New North American Species and New Assignments in the Genus Chionodes (Lepidoptera: Gelechildat). Fash. Acad. Sci. Jour. 37 (7): 243-254. July. 


\section{TAXONOYY-Continued}

(255) Clarke, J. F. Gates

llotes on, and Hew Species of, American Moths of the Genus Mlat1ma Busck (Gelechi1dae:Lopidoptera). Wash. Acad. Scl. Jour. 37 (8): 263-275. August.

Notes on Oecophorldae, With Descriptions of New Specles. Wash. Acad. Sc1. Jour. 37 (1): $2-18$. January.

(257)

The Faune and Flon of the II Segundo Sand Dunes. A Net Fucoara Prom the EI Segundo Ssnd Dunes. (Olothreutidae: Lepldoptera.) South. Cal1f. Acad. Sc1. Bul. 46 (1): 35-50. January-Apri1.

(258) Cranford, J. C.

\& Now Spec1es of the Genus Haplothrlps, Subgeaus Hadothrips (Thysanoptera: Phlaeothripldae). Wash. Ent. soc. Proc. 49 (9): 250-251. December.

(259)

I Ner Specles of the Genus Metrlothrips (Thysanopteras Phlaoothrlp1dae). Mash. Bnt. Soc. Proc. 49 (8): 229-230. Iovember.

$(260)$

Tbe North Amerlcan Species of the Genus Megelothrips Uzel (Thysanoptera:Phlaeothrip1dae). Mash. Ent. Soc. Proc. 49 (7): 197-199. 0ctober.

(261) Cushman, R. A.

$\triangle$ Goneric Reviston of the Ichnoumon-Fies of the Tribs Ophlonin1. J. S. Nat1. Has. Proc. 96 (3206): 417-482.

(262) Eulng, H. E., and Baker, E. F.

Honyssus Lanesoni, a New Liponysald utto (Acarina: Lrelaptidae) from Blarlna brevicauda (Say). Jour. Parasitol. $33(4)$ : 376-379. Angust.

(263) F1sher, W. S. New Cerambycid Beotles Belonging to the Tribe Rhinotragini. ठ. S. Met. Mus. Proc. 97 (3209): 47-57.

Now Neotroplcal Cerambycldse Belonging to the Genus Doreart parcoe (Coloopters). Rev. de Ent. $18(1-2)$ : 173-182. Augrist.

Hew Nest Indian Cerambrcid Beotler. IV. Soc. Cubana de Hist. lat. "Folipe Posy" Eem. 19 (I): 29-4l. July. 


\section{TAXONOMY--Continued}

(266) Gahan, A. B., and Ferriere, Ch.*

Dotes on Some Gall-Inhablting Chalcldoldea (Bymenoptera). Ent. Soc. Amer. Ann. 40 (2): 27-302. June.

(267) Gurney, A. B.

A New Specles of Pristoceuthoph1 lue from Orsgen, and Remarks on Certain Special Glands of Orttoptore (Gryllacrididae: Rphaphidophorings). Wash. Acad. Sc1. Jour. 37 (12): $430=$ 435. Deceraber.

(268)

Notes on Dilaridae and Berothidae, 渻th Speclal Reference to the Inmeture Stages of the Nearctic Generg (Neuropters.). Psyche 54 (3): 145-169. September.

(269)

Notes on Somo Remarkable Australastan Folksagstsecs, Includtros a Synopsis of the Genus Extratosoma (Orthoptera: Phasartidae). Ent. Soc. Amer. Ann. 40: 373-396. Septombor.

(270) Hsiao, Tslogr, and Saller, R. I.

The Orchld Bugs of the Genus Tenthecoris Scott (Hemipters: Miridae). Wash. Acad. Sc1. Jour. $37(2): 64-72$. Fobruary.

(27) James, M. T.

A Revien of the Larvaevorid Flies of the Tribe Lesklinf Fith the Setulose First Vein $\left(B_{1}\right)$. O. S. Matl. Mus. Proc。 97 (3212): 91-115.

(272) Mason, Preston W.

A New Pear Aphid (Homopteras Aph1dae). Hash. Ent. Soc. Proc. 49 (9): 252-254. Docerber.

(273) Muesebeck, C. F. T.

Two Ne Species of Apanteles from California (Hyenoptera: Bracecidae). Pan-Pacific Ent. 23 (1): 21-24. January.

(274) Oman, P. . .

Miscellaneous Notes on Clcadellidae (Homoptera). N. Y. Ent. Soc. Jour. 55: 59-63. Harch.

(275)

The Types of Auchenorrhynchous Homoptera In the Iowa State College Collection. Iora Stato Col. Jour. 8c1. 21 (2): 161-228. January.

(276) Rees, Bryant, B.

Taxcnomy of the Larrme of Some North Amerfean Novilinf

(Coleopterar Coccinallida). Pan-Pacific fat. 23 (3): 133-119. July. 


\section{TLXOYOMT-Continued}

(277) Rees, Bryant $\mathbf{B}$.

Taronom of the Larvae of sone Morth Anericen Spectes of the Genus Derestes (Coleopteres Dermestidno). Dnt. Soc. Wanh. Proc. 49 (1): 1-14. January.

(278) Russell, L. U.

A Classification of the Mhiteflios of the Hew Tribe Trialeurodini (Bomopteras Aleyrodidae). Rev. de But. 18 $(1-2): 1-44$. August.

(279) Sabroaky, C. F.

A Now Pterodont1a from New Guinea. Pan-Pacific Eat. 23 (2): 74-75. Apr11.

(280)

A New Species of the Dipterous Fanily Astelldae from Hawal1. Hawa11. Ent. Soc. Proc. 13 (1): 55-57. Mer.

(281)

A Revision of the African Genus Epimadiza Becker. Ann. and Mag. Hat. B1 st. 13 (108): 821-851. October.

(282)

A Synopsis of the Larverorid Flies of the Genus pudefeania U. S. Nat1. Mus. Proc. 97 (3215): 141-156.

(283)

Rhodeslella: A Genus New to the Nestern Hemisphere (Dipteras Chlorop1dae). Ent. News 58 (7): 174-177. July.

(284)

The Significance of the "Editorial Notes" In the Reprints of the Earlier Oplnions on coological Nomenclature. Ent. Soc. Amer. Ann. 40 (1): 152-153. Karch.

(285) Saller, R. I.

Drsdercus bimaculatus Stal. 1850, Restored (Hemiptera: Pyrrhocoridae). Ent. Soc. Mash. Proc. 49 (1): 15-19. January.

(286) Smith, Carroll N., and Gouck, Harry K.

Ixodes bishopp1, A New Specles from Georg1a. Int. Soc. Amer. Ann. 40 (1): 75. Warch.

(287) Sanith, M. R.

A Generlc and Subgeneric Synopsis of the Onjted States Ants, Based on the Norkers (Hymenopteras Formlcidae). Amer. Midland Nat. 37 (3): 521-647. May. 
TAxoNorI-Continued

(289) Smith, M. R.

1 Hew Genus and Species of Ant Fron Guatemala (Hymenoptera:

Forntcidae). H. I. Int. Soc. Jour. 55 (4) : 281-285.

Decenbor.

(290)

A New Genus of Megelomrnez from Barro, Colorado Island, Canal Zone (Byenopteras Fornicldae). Fat. Soc. Wash. Proc. 49 (4): .101-103. Apr12.

(291)

A New Specles of Metapone forel from New Gulnea (Hymenopterat Formicidae). Fat. Soc. Fash. Proc. 49 (3) : 75-77. February.

(292)

A Study of Polyergus in the Enlted States, Based on the Morkers of (Bymenopterai Fomlcldae). Aner. Midland Mat. 38 (I) t 150-161. July.

(293)

Ints of the Genus Crrptocerus F. in the Unt ted Statos. Fat. Soc. Amer. Proc. 49 (1): 29-40. January.

(294)

Notes on Pheldole (Decapholdole) and the Description of a New

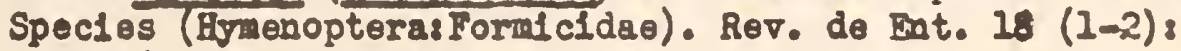
193-196. August.

(295) Stone, Alan

¿ New Procecldochares from Dupatorlum Stens (Diptera:

Tophritidae). Hawal1. Ent. Soc. Proc. 13 (1): 97-98. May.

(296)

A Topotypic Male of Aedes scutellaris (Walker) (Dipters: cullcidae). Ent. Soc. Hash. Proc. 49 (3): 85. Fobruary.

(297) and Penn, G. H.

A New Species of Culex from New Guinea (Dipteras Culicida.) Fash. Acad. Sc1. Jour. 37 (3): 89-91. March.

(298) and Wirth, w. W.

On the Marine Midges of the Genus Clunio Hallday (Diptera: Tendipodidae). Ent. Soc. Wash. Proc. 49 (8): 201-225. Hovember.

TRUCK CROP, GARDEN, AND GREENHOUSE IMSECTS

(299) Allen, Norman, and Early, J. D.

Experiments With DDT as a Control for the Tobacco Budworm.

S. C. Agr. Expt. Sta. Ann. Rpt. 59: 119-127. September. 
TRUCK CROP, GARDEN, AND GREENHOUSE INSECTS (ContiDUEC)

(300) Allen, Norman and Pollard, P.N.

Baits to Control Green June Beetle Larvar in Tobacco-Plant

Beds. Jour. Econ. Ent. 40 (5) \& 655-660. October.

(301) Bare, C. 0., Tenhot, Joseph N., and Brubaker, Ross W.

Improved Techniques for Mass Rearing of the Clgarette

Beetle and the Tobacco Moth. U. S. Bur. Pint. and Plant

Quar. ET-247, 11 pp., 111us. Novamber. [Processed.]

(302) Bowen, 1. F.

Population Distribution of the Beet Leafhopper (Eutettix tennellus Baker) in Relation to Experimental F1eld Plot Layout. Jour. Agr. Res. 75 (11-12): 259-278. December.

(303) Brannon, I. W.

Further Tests for Control of Mexican Bean Beetle and Corm Earworm on Snap Beans. Jour. Econ. Ent. 40 (1): 103-106. February.

(304) Brierley, P., Smith, F. F., and Mckhorter, F. P.*

Symptoms and Controls for Diseases of Eastern Lilies. Florists' Rev. 100 (2597): 41-45. September. Also South. Florlst and Nursexman 60 (32): 11, 57, 60; (33): 12-13, $63-64,66$. November 7 and 14 .

(305) Brindley, T., Hinman, F. G., Schopp, R., and Manis, H. C. Effectiveness of DDT for Controlling Pea Heevll Confirmed. Idaho Agr. Expt. Sta. Ann. Rpt. 54 (Bul. 269): 33. July.

(306) Cockerhan, K. I., and Deen, O. T. Reslstance of New Sweetpotato Seedlings and Parleties to Attack by the Sweetpotato Feev11. Jour. Econ. Ent. 40 (3) : 439-441. June.

(307) Deen, O. T., and Harrison, P.K. New Insect1cides Show Proulse for Cabbage Caterplilar and Turnip Aphid Control. La. Agr. Expt. Sta. Ann. Rpt. (Research in Agriculture) 1945-1946: 113. June.

(308) Harrison, P. K., and Doen, 0. T.

Insectlcide Studies During 1946 Show Promise of Controlling the Sweotpotato Feevil. La. Agr. Expt. Sta. Ann. Rpt. (Research in Agriculture) 1945-1946: 112-113. June.

(309) Ditman, L. P., Smith, F. F., and Burkhordt, Geo.*

Ilquefled Gas Aerosol for Pea Aphid Control. Third Report. Jour. Econ. Ent. 40 (2): 190-194. April.

(320) Doucette, C. F.

Host Plants of the Cabbege Seedpod Weevil. Jour. Econ. Int. $40(6)$ : $838-840$. Decouber. 
TRUCK CROP, GARDEN, AND GREENHOUSE INSECTS-ContInued

(311) Doucette, C. F.

Stom Borer Attucking L111es. (Sclent1fic Note) Jour. Econ.

Ent. 40 (6): 918. December

(312) Douglas8, J. R., Shirck, F. H., and Manis, H. C.

Onion Thrips Controlled. Idaho Agr. Expt. Sta. Ann. Rpt.

54 (Bul. 269): 31-32.

(313) Dudley, J. E., Jr.

Phytotoxicity of DDT Dusts and Sprays to Truck Crops in

Hisconsin. U. S. Bur. Bht. and Plant Guar. E-75, of pp.

Merch. [Processed.]

(314) Landis, B. J., and Dav1s, E. F.

Two-spotted Spider Mite Damage to Potatoes. (Scientific Note) Jour. Econ. Int. 40 (4) \& 567. August.

(315) Poos, F. F., Grayson, J. U., * and Batten, E. T.*

Insectlcides to Control Tobacco Thrips and Potato Leafhopper on Peanut8. Jour. Eccin. Ent. 40 (6), 900-905. December.

(316) Scott, L. B., and M1lam, Joe

Tests With Polsoned Balts and Attractants for Woths of the

Tobacco and Tomato Hornworms. J.S. Bur. Ent. and Plant Quar. E-735, 16 pp. September. [Processed]

(317) Shands, H. A., Simpson, G. W., Flynn, C. M., Lung, P. H., and Seaman, B. A.*

Potatoes. Matne Agr. Bxpt. St8, Bul. 449, pp. 283-293. June.

(318) Simpson, G. K., Bonde, R.,* Plumwer, B. E., Jr.,* Shands, H. A., Sinith, F. F., Bronson, T. E., Lomberd, P. M., and Lung, P. H.

How to Use DDI on Maine Potatoes. Maine Agr. Col. Ext. Bul. $361,10 \mathrm{pp}$. May.

(319) Sint th, F. F.

Control of the Gladiolus Thrips in the F1eld and Storage House. Glad Book [Falne Gladiolus Soc] 1947: 26-28.

(320) and Boswell, A. L.*

Preliuinary Ixperimants Fith DDr and Benzone Bexachloride Agatnst tho Gladiolus Thrips. Gladiolus Mag. For Fngland Gladiolus Soc. 11 (3): 10-13. July.

(321) and Brierley, P.*

Camation and Gladiolus Virus Dlseases Pose Serlous Problens. Flor1sti' Rev. 99 (2567): 31-33. February 6.

(322) _ and Brierley, P.*

Virus Diseases of Gladiolus. Qladiolus Mag. EFew Fagland Gladiolus Soc. 11 (1): 16-18. Fobruary. 
TRUCK CROP, GARDEN, AND GREENHOUSE INSECTS--Continued

(323) Smith, F. F., Ditman, L. P., and Burkhardt, George*

Liquefied Gas Aerosols for Pea Aphid Control: Third Report. Jour. Econ. Ent. 40 (2): 190-194. April.

(324) Fulton, R. A., and Brierley, Philip*

Use of DDT and HETP as Aerosols in Greenhouses. Part I. Agr. Chen. 2 (12): 28-31, 61. December.

(325) Smith, R. A.,* Fulton, R. A., Lung, P. H., and Brierley, P.* Potent New Insecticides and New Methods Undergo Thorough Trial. Florlsts' Rev. 99 (2569): 31-35. February.

(326) Tenhet, Joseph N.

Effect of Sublethal Dosages of Pyrethrum on Oviposition of the C1garette Beetle. (Scientific Note) Jour. Econ. Ent. $40(6): 910-911$. December.

(327)

Pyrethrum-0il Sprays in Open-Type Warehouses. U. S. Bur. Ent. and Plant Guar. E-717, 5 pp. April. [Processed.]

(328) White, W. H.

Insecticides for Vegetables. U. S. Dept. Agr. Yearbook

(Science in Farming) 1943-1947: 663-669.

BIBLIOGRAPHIES, LITERATURE REVIEWS, AND LISTS

(329) Busbey, Ruth L.

A List of Publications on Benzene Hexachloride. U. S. Bur. knt. and Plant Quar. E-731, 22 pp. July. [Processed.]

(330) Gaddis, B. 枯.

A Review of Pest Surveys, Both National and State, Fhich Have Been Under Way for the Past Year. Western Plant Board Conf. Rpt. 28: 86-101. June.

(331) and Roberts, R. A.

Review of the Golden and Potato Rot Nematodes. Nesterm Plant Board Conf. Rpt. 28: 75-84. June.

(332) Hall, Dav1d G.

An Unusual Artist. [A. J. Cushman] Acco Press 25 (6): 14. June.

(333) MeIndoo, N. E.

A Review of the Insecticidal Uses of the Rotenone-Bearing Plants, 1938-1944. U. S. Bur. Ent. and Plant Guar. E-713, 201 pp. February. [Processed.] 
BIBLIOGRAPHIES, LITERATURE REVIETS, AKD LISTS-COntinued

(334) Roark, R. C.

$\Lambda$ Dgest of Information on Hexaethyl Tetraphosphate. U. S. Bur. Bnt. and Plant Quar. E-721, 12 pp. April. [Processed.]

(335) and MaIndoo, N. Z.

A Third Digest of the Literature on DDT (January through June 1945). U. S. Bur. But. and Plant Guar. E-728, 164 pp. Juse. Processed.]

(336) Stage, H. H.

101 New References of Interest to Mosquito Control Norkers.

N. J. Mosquito Extermin. Assoc. Proc. 348 198-205. April.

(337)

References to Ilterature of Interest to Mosquito Control

Norkers. Mosquito News 7 (1): 48-54. March; (2): 96-101, June; (3): 129-137, Septexber; and (4): 174-177. December.

\section{UISCELIANEOUS}

(338) Nllen, H. H., and Brunson, M. H.

Control of Nosema Disease of Potato Tuberworm, a Host Used in the Mass Production of Macrocentrus ancylivorua. Sclence 105 (2728): 394-395. April.

(339) B1shopp, F. C.

The Tax Fie Pay to Insects. U. S. Dept. Agr. Yearbook (Sclence in Farming) 1943-19478 613615.

(340) Black, L. M., and Oman, P. ..

Parthenogensis in a Leafhopper, Agallia quadripunctata

(Provancher) (Homoptera: Cl cadellidae). Int. Soc. Fash.

Proc. 49 (1): 19-20. January.

(341) Haeussler, G. J.

Reports on Insect Conditions: Agr. Chem. (Listening Post)

2 (1) : 49-50, January: (2): 41, 43, February; (3): 41, 43,

March; (4): 46, April; (5): 41, 43, May; (6): 51-52, 69-70, June; (7): 49, 5I-52, July; (8): 45, 57, August; (9): 47 , 49, September: $(10): 47,49$, October; (11): 45, 67, November: (12): 41, 43, December.

(342) Popham, พ. I.

Use of Chemicals to Control Golden Nematode. Agr. Chem.

2 (5): $30-33,69,71$. Lay.

(343) Rohwer, S. A.

Greetings to I. 0. Howard, Ent. Soc. Fash. Proc. 49 (6): 146-147. June. 


\section{MISCELLANEOUS-ContInued}

(344) Stage, H. H. DDT Has a Namesake in Dutch Guian (An Application of DDT to Cognomination). Mosquito News 7 (2): 55-5\%. June.

(345) Nade, J. S., and Caffrey, D. J. Obltuary of Rufus Hiram Pettit. Ent. Soc. Mash. Proc. .49 (3): 87. Narch. 
Lamodt, 0. S. .................. 31 Acreo, Fred, Jr. .............. 155 Alderdlce, J. A. .............. 39 Allen, В. .................... 338 Allen, Worman .............. 299, 300 Anderson, L. D. ................. 204 Anderson, Roger F. .............. 72 Anderson, พ. H. ............ 244, 245 Arbuthnot, K. D. ............. 14, 15 Baker, E. K. ............... 246, 262 Bakrer, พ. A. .............. 16, 17, 18 Barber, H. S. .......... 247, 2/8, 249

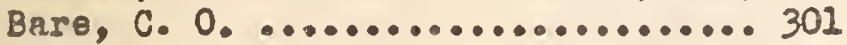
Barnes, D. F. ......... 97, 98, 99, 130 Barnes, E. C.*............... 52 Barthe1, M. F. ................. 157 Batton, E. T.* ................. 315 Bayles, B. B. ................ 31 Beal, J. A. ................. T9 Becker, G. C. .................... 239 Berlin, F. D. ............... 56, 57 Berry, Paul A. ........... 19, 73, 100 Bess, Eanry A. .................. 74 Blrd, H. R.* ................... 179 B1shopp, F. C. ......... 167, 183, 339 Black, I. U. ................... 340 Blakeslee, E. B. ............ 184, 185 Bochert, R. S., Jr. ........... 57 Bodensteln, H. G. ............... TO Bohart, G. E. ................. 1 Bonberg, J. .. ................ 75 Bonde, R. ........................ 318 Bondy, F. F. ............... 37, 51 Boswe1l, A. L.*............... 320 Bottger, G. T. ............. 168, 177 Bowen, C. H.* ................. 111 Bowen, C. V. ........... 138, 153, 180 Bожеn, K. F. ................... 302 Bradley, W. G. ................. 18 Brannon, I. W. .............. 169, 303 Brewer, E. G. .................. 76 Brlerley, P.* ...... 304, 321, 324, 325

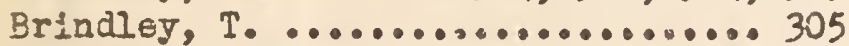
Bronson, T. E. ................ 318 Brubaker, Ross î.................. 301 Bruce, W. G. ....... 184, 185, 186, 202 Brunson, K. H. ................. 338 Buchanan, I. I. ........ 250, 251, 253 Burgess, E. D. ................. 54 Burkhardt, Geo.* ........... 309, 323

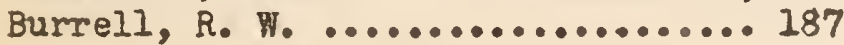

Busbey, Ruth L. ....... 137, 154, 329

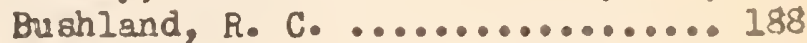
Bynum, E. B. ........ 26, 27, 28, 29 Caffrey, D. J. ............... 345 Caley, T. T. ................ 52 Carlson, F. T. .................... 136 Carter, R. H. ......... 139, 140, 179 Carter, S. T. ........... 14, 15, 30 Cartwight, ז. B. ........ 20, 21, 53 Caster, A. B.* ................ 9 Chamberlin, R. T. ............. 35 Chapman, A. J. ............ 38, 43 Cherpentier, L. J. .......... 26, 27 Chishol, R. D. ............54, 141 Chr1stenson, L. D. ............ 212 Clancy, D. W. ................ 200 Clarke, J. F. Gatos .... 253, 254, 255 256,257 Cockerham, K. I. ...... 306, 307, 308 Condst, Ira J.* ............... 225 Conn, W. E. .................. 39 Connin, R. V. ............... 34 Cook, W1111an C............... 55 Cooley, C. E. ................ 240 Corl1ss, J. U. ................ 77 Cosenze, A. V. ................ 30 Cotton, R. T. ......... 241, 242, 243 Cowan, F. T. .................. 25 Crawford, J. C. .......258, 259, 260 Cristol, S. J. ............. 1/4, 143 Cupples, H. L. ................. 144 Curl, L. F. ................... 40 Cushran, R. A. ................. 261 Dav1s, E. W. ...............58, 314 Deen, 0. T. .......... 306, 307, 308 Deonier, C. C. ............. 187, 197 Ditsan, L. P. ............. 309, 323 DI

Man and Animals .............. 189 Doucette, C. F. ........... 310, 311

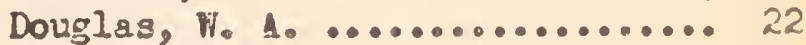
Douglass, J. R. .............. 312 Dowden, Phil1p B.............. 78 Dudley, J. E., Jx. ............ 313 Dugas, A. L. ................. 29 Dunnam, E. W. .................. 45 Early, J. D. ................. 299 Eaton, C. B. ................. 79 Eddy, G. W. .................... 190 Evenden, James C. Ewing, H. E. ................. 262 
Ewing, K. P. .......... 41, 42, 48, 49 Fahey, J. E. ............... 131, 145 Fries, J. B. .........52, 62, 63, 64, $170,177,203$

Farrar, C. I. .................. 2, 3 Fate, L. B. .................. 81 Fenner, L. K.................... 81 Ferrlere, Ch. ................. 266 Fest, W. C. .................... 54 Fife, L. C. ............... 38, 43

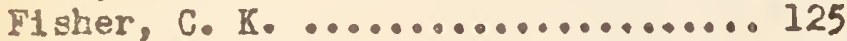
Fisher, T. S. ..........263, 264, 265 Fleck, E. E. ................ 146, 147 Fleming, K. E. . 102, 103, 104, 105, 106

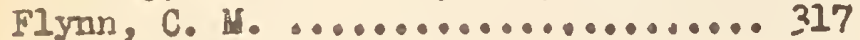
Frenkenfeld, J. C. ............. 242 Frost, Marvin H., Jr.* ............ 9 Fulton, R. A. ....... 56, 57, 137, 148, $170,324,325$

Gaddis, B. H. ........... 23, 330, 331 GaddIs, C. H. .................. 170 Gahan, A. B. .................. 266 Gahan, J. B. ............... 182, 191 Gaines, R. C. ................. 44 Gersdorff, W. A. ........... 177, 192 Gertler, S. I. ............ 149, 171 Getzenduner, C. R. .............. 58 Gigliol1, George* .............. 223 Gillette, H. P. S.* ..............224 Gjuliin, C. H. ............. 193, 228 Gooden, E. I. ............... 150, 166 Goodhue, L. D. ...... 60, 107, 151, 152 Gouck, H. I. ............ 194, 219, 286 Grahame, 0. H. ............... 218 Grayson, J.M.*............ 24, 315 Green, Nathan ................. 179

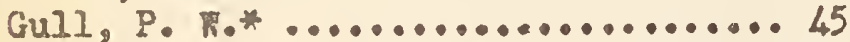
Gumey, A. B. .......... 267, 268, 269 Hadley, C. H. ................... 108 Haeussler, G. J. ................ 347 Haley, W. E. ................... 27 Ha11, Dav1d G. ... 4, 82, 172, 173, 332 Bal1, Stanley A. ................. 162 Haller, H. I. . $143,153,154,156,161$,

Kambleton, J. I. ............. 5, 6 Berilton, D. $. . \ldots \ldots \ldots \ldots . . . .109,110$

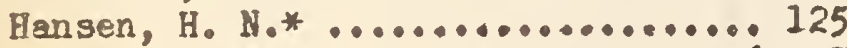
Harned, R. W. ................ 46, 47 Harrison, P. K. ................... 307, 308 Hartman, H. J. ................. 229 Hazen, A. C. ................. 152
Henderson, L. S. ........ 52, 195, 196 Henry, B. T. .................. 236 Hensley, $H, S . . . \ldots \ldots \ldots \ldots \ldots . . . . .559$ Hepting, G. H.* ............. 83, 238 Hinman, E. J. .................. 25 Hinman, F. G. ................ 305 Hochberg, S. ..............203, 204 Hodges, $\mathbf{K}_{*} \ldots \ldots \ldots \ldots \ldots \ldots \ldots \ldots . . . . .203$ Hoffman, C. H. ................ 83 Hollon, J. P. ................. 129 Holst, E. C. .................. 7 HsLa., Tsi-gu ............... 270 Bunt, Geo. W. .................. 84


Incho, H. H. ........................ 197 Ingrain, J. H. ......... 26, 27, 28, 29 Irons, F. .....................181 IVY, E. E. ............ 42, 48, 49 Jacobson, H. .............. 155, 156 James, M. T. ................. 27 Jaynes, H. A. ................. 79 Johnson, A. C. .............. 111 Johnson, I.*............... 204 Jones, D. F. ............. 14, 15, 30 Jones, H. A. ................. 209 Knipling, E. F. .... 198, 199, 200, 225 Kobl1tsky, L. .............. 54, 141 Kouba, T. F. ................. 236 Laake, E. W. .............. 201, 202 LeForge, F. B. .... 157, 158, 159, 163, 164,165 LoHer, V. X.* ............. 203, 204 Land1s, B. J. ............... 314 Lane, Merton C. ................ 55 Latta, Randall ......... 60, 203, 204 Lauterbach, H. ............... 204 Levin, Clemence ................ 168 Limber, D. P. ............... 230 Lindgren, D. L. .............. 98,199 Lindquist, A. H. .. 205, 206, 209, 210 , 211,215 Linduska, J. P. ........... 207, 208 Littlefield, E. W.* ............. 74 Lloyd, G. W.* ............... 14, 15 Lombard, P. H. ................ 318 Long coy, 0. H. .............. 59, 210 Luginbill, Philip .............. 53 Lung, P. H. ........... 317, 318, 325 Mackensen, otto .................. 8 Madden, A. H. .. 88, 205, 209, 210, 211 Maines, Warren W. ........... 105, 106 Manis, H. C. .............. 305, 312 
Kann, H. D. ................... 6I Uartin, J. F. .................. 231

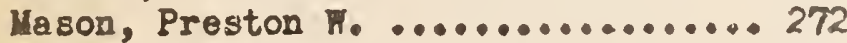
Mathes, Ralph ................. 28 Math1s, Uayer, E. L. ............... 175, 176

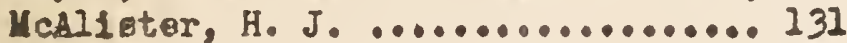
MoGovran, E. R. 62, 63, 64, 170, 177,214 MeGregor, S. E. ............... 9, 10 McIndoo, N. E. .............. 333, 335 Yckhorter, F. P.* .............. 304 M1lan, Joe ................... 316 M1llíron, Н. Е.............. 85, 86 Morton, F. A. .......... 207, 208, 220 Noznette, G. F. ............. 113, 114 Muesebeck, C. F. T. ............... 273 Kuiry, J. $T_{0}$.................. 79 Nelson, Howerd D. ............... 137

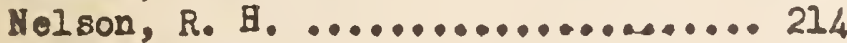
Newcomer, E. J. ......... 115, 116, 117 N1ckels, C. B. .................. 118 Noble, R. B. .................... 21 Oertel, Everett ................. 11 offord, H. R. .............. 229, 232 Oman, P. .......... 212, 274, 275, 340 Orlando, Fla., Laboratory ......... 213 Packard, C. K. .................. 3I Parencla, C. R., Jr........... 42, 49 Parker, J. R. .................. 32

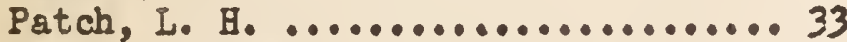
Payne, George C. ................. 191 Ponn, G. H. ..................... 297 Ph1lilps, A. H. ................ 182 Phillips, G. I. ................ 111 Plerce, F. C. .................. 118 Plquett, P. G. ................ 214 Pluwmer, B. E., Jr.* ............ 318 Plumer, C. C. ............. 119, 120 Pogorelakin, .. A. .............. 161 Pollard, H. N. .................. 100 Pollard, P. H. ................. 300 Poos, F. H. ............... 24, 315 Popham, F. L. .................. 342 Porter, B. A. ............... 121, 122 Potts, S. F. ............ 65, 66, 87 Prout, C.* .................... 233 Putnam, H. N. ................. 234 Questel, D. D. ................. 34

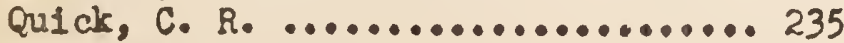
Rainwater, C. F. ............ 50, 51 Rees, Bryant E. ............276, 277 Richmond, C. A. .................. 38
RIker, A. J. ................. 236 Rinell1, W. R. ............... 52 Ritter, L. B. ...............233 Roark, R. C. .......... 160, 334, 335 Roberts, R. A. ............23, 331 Rockrood, L. P. ............... 35 Rogers, E. E. ................ 204 Rohwer, S. A. ............ 178, 343 Romey, V. E. ................. 888 Roth, A. R. .............. 206, 215 Roth, E. R.* ................. 83 Pubin, $\operatorname{Max} \ldots \ldots \ldots \ldots . . . . . . . . . .179$ Rude, C. S. .......... 216, 217, 218 Rusk, Harold .............. 67, 145 Russe11, L. Y. ................ 278 Sabrosky, C. F. ....... 279, 280, 281 $282,283,284$

Sailer, R. I. ............ 270, 285 Sanders, D. A. ................ 185


Schechter, U. S. ........... 149, 161

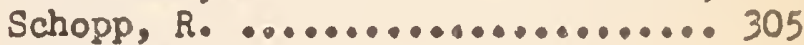
Schroeder, H. 0............... 211 Scott, L. B. ................ 316 Seaman, B. A.* ............... 317 Shands, W. A. ............. 317, 328 Shar, J. G. ....... 119, 120, 123, 124 Sheels, R. A. ................. 89 Sh1ller, Ivan ................ 43 Sh1rck, F. H. ............... 312 Siegler, E. H. ........ 68, 162, 180 Simmons, Perez .............69, 125 Simpson, G. W. ............ 317, 318 S1sson, .. A. ................ 237 Smith, C. E. .................. 29 Sintth, C. N. .......... 194, 219, 286 Solth, F. F. ..... 304, 309, 318, 319 $320,321,322,232$ 324,325

Smith, G. L. ................ 44 Smith, H. R. .....2287, 288, 289, 290 $291,292,293,294$

Smith, R. A.* ................. 325 Snapp, Oliver I. .. 126, 217, 128, 129 Snyder, F. H. ................. 220 Snyder, T. E. ........ 84, 90, 91, 92 Soloray, S. B. .... 143, 158, 159, 163 164,165

Spencer, R. A.* ................. 66 Spurr, Stephen H.* .............. 74 St. George, R. A. ...........99, 95 Stafford, E. M.* .............. 130 
Stage, H. H. ..... 181, 221, 222, 223, $224,225,226,337,344$

Steiner, L. F. ................ 131 Stone, Alan ...... 295, 296, 297, 298 Struble, G. R. ................. 93 Sturtevant, A. P............... 12 Summerland, S. A. .............. 131 Swingle, M. C. ................ 182 Talley, Florence B. ........... 175 Tenhet, Joseph N. ...... 310, 326, 327 Tissot, A. H. ................. 185 Todd, Frank E. .................. 13 Travis, B. V. ............ 226, 227 Tyler, J. G.* ................ 125 Van Dyke, Mllared J. ........... 148 Van Leeuwen, E. R. .............. 132 Vansell, Geo. H. ................. 13 Vorhies, C. T.* ................ 10 Wade, J. S. .................. 345 Falkden, H. H. ................ 243 Well, L.* .................... 176
Item

Fe1s8, Freeman* ................. 94 We1sser, J.* ....................166 Tester, Horace $\nabla . * \ldots \ldots \ldots \ldots \ldots \ldots \ldots . . . . . . .95$ White, Ralph T. ............... 133 White, H. H. .................. 328 Whitten, R. R. ................... 88 WIIson, C. C. ................. 36 H1lson, H. G. ................. 205 WIson, I.* .................. 203 Wirth, W. W. ................... 298 W1 secup, C. B. ................... 187 Woodwrard, C. F. ........... 175, 176 Zates, W. W. ............... 215, 228 Yeomeans, A. H. ................... 70


Yost, H. E. .................... 238 Yotbers, M. A. .............. 135, 136 Young, M. T. .................. 44 Iu111, J. S. ................... 96 Yust, Harold R, ................ 137 Zimerman, S. $\mathbb{K} . \ldots \ldots \ldots \ldots \ldots \ldots \ldots \ldots .35$ 